профессиональные контакты на английском языке, как в сфере IT, так и в различных ситуациях.

$$
* * *
$$

1. Дорогайкина Е. М. Иностранный язык в техническом вузе: вопросы преподавателей-практиков // Решетневские чтения.- Красноярск. - 2017. - Т.2. С.610-612

2. Юрьева Ю. С. Языковая профильная подготовка в условиях непрерывного образования // Сибирский педагогический журнал. -2010. - № 1. - С.151-164.

3. Пассов Е.И. Коммуникативный метод обучения иноязычному говорению / Е.И. Пассов. - М.: Просвещение, 1991.

4. Гурвич П.Б., Григорян С.Т. Усиление мотивации учебной деятельности, направленной на овладение лексикой иностранного языка / П.Б. Гурвич, С.Т. Григорян // Иностранные языки в школе. - 1976. - №6. - С. 50-55.

5. Зимняя И.А. Педагогическая психология / И.А. Зимняя. - Ростов - на - Дону: Феникс, 1997. - 480 c.

6. Головин С.Ю. Словарь практического психолога / С. Ю. Головин // Минск: Харвест, 1998. -800 с. 7. Головей Е. И. Психология популярных профессий // СПб: Речь. $-2003 .-256$ с.

\title{
Болотников А.А. \\ Студенческое самоуправление как условие формирования личностных и профессиональных качеств обучающихся предпринимательского вуза
}

Университет управления «ТИСБИ» (Россия, Казань)

doi: 10.18411/lj-02-2021-121

idsp: ljournal-02-2021-121

\section{Аннотация}

Актуальность исследования обусловлена необходимостью повышения значимости воспитательной работы в современном вузе и поиске эффективных форм деятельности, способствующих профессиональному становлению студентов - будущих предпринимателей. Цель исследования - выявить субъектную позицию студентов предпринимательского вуза о студенческом самоуправлении как условии формирования и развития их личностных и профессиональных качеств. Установлено, что участие в студенческом самоуправлении способствует формированию, совершенствованию и развитию личностных и профессиональных качеств обучающихся - будущих управленцев. Выявлены наиболее предпочтительные для студентов направленности мероприятий, организуемых студенческим советом. Определен пул значимых для студентов предпринимательского вуза личностных и профессиональных качеств, формируемых в процессе студенческого самоуправления и необходимых для их будущей профессиональной деятельности.

Ключевые слова: студенческое самоуправление, профессиональное развитие, профессиональная подготовка, личностные и профессиональные качества управленца, субъектная позиция.

\section{Abstract}

The relevance of the study is due to the need to increase the importance of educational work in a modern university and to search for effective forms of activity that contribute to the professional development of students - future entrepreneurs. The purpose of the study is to identify the internal position of business university students on student self-government as a condition for the formation and development of their personal and professional qualities. It is established that participation in the relevance of the study is due to the need to increase the importance of educational work in a modern university and the search for effective forms of activity that contribute to the professional development of students - future entrepreneurs. The purpose of the study is to identify the subjective position of students of an entrepreneurial 
university about student self-government as a condition for the formation and development of their personal and professional qualities. It is established that participation in student selfgovernment contributes to the formation, improvement and development of personal skills.

Keywords: student self-government, professional development, professional training, personal and professional qualities of a teacher, subjective position.

Введение. В условиях модернизации и системных изменений в образовании управленцу необходимо обладать определенным комплексным пулом профессиональных качеств, приобретаемых преимущественно в процессе профессионального развития. Внедрение инновационных образовательных технологий, форм, средств и методов организации образовательного процесса требует от управленческих работников повышения профессиональной компетентности, развития их личностных и профессиональных качеств.

Особо значимыми этапом профессионального становления будущего управленца является профессиональная подготовка, определяющая траекторию дальнейшего развития личности как специалиста. В период обучения в образовательной организации высшего образования происходит «осознанное стремление к самореализации, определяются основные направления жизненных позиций» [2]. Для успешного профессионального становления и развития личности требуется систематическое усовершенствование и расширение профессиональных компетенций [8]. Необходимые профессиональные компетенции, личностные и профессиональные качества студентов формируются, совершенствуются и развиваются в процессе профессиональной подготовки не только в учебной, но и во вне учебной деятельности. В связи с чем, важным становится создание благоприятных условий для их развития и самореализации, одним из которых является формирование воспитывающей среды «среды созидательной деятельности, общения, разнообразных событий, возникающих в них отношений, демонстрации достижений» [1].

В.А. Ясвин рассматривает образовательную среду как территориально и событийно ограниченную совокупность влияний и условий формирования личности, а также возможностей для ее развития [12]. В.Е. Цибульникова подчеркивает, что образовательная среда выступает как «единый и неделимый фактор внутреннего и внешнего психосоциального и социокультурного развития личности» [7]. Образовательная и воспитывающая среды способны обладать признаками культуросообразности, аксиологичности, адаптивности, здоровьесозидания, рефлексивности, билингвальности, безопасности и др.

При этом В.В. Самородовой отмечается, что фактором формирования социально безопасной среды современного вуза выступает студенческое самоуправление [4]. Развитие студенческого самоуправления способствует формированию у обучающихся самостоятельности, лидерских качеств, социальной направленности и созидательной активности. Эти важные качества необходимы будущему управленцу в его дальнейшей профессиональной деятельности.

В связи с чем, важной и актуальной формой воспитательной работы в вузе является студенческое самоуправление, позволяющее будущим предпринимателям проявлять инициативу в организации и участии в различных видах деятельности духовно-нравственной, социальной, патриотической, физкультурно-спортивной и иной направленности.

Студенческое самоуправление как целенаправленная деятельность студентов предполагает их активное участие в принятии решений, связанных с жизнью вуза и отельных его подразделений (факультетов, общежитий, студенческих объединений и др.), проявление инициативы обучающихся по организации их досуга и удовлетворению потребности в самореализации. 
Студенческое самоуправление выступает и системообразующим элементом организационной культуры предпринимательского вуза, «ценности организационной культуры выступают в качестве магистрального мотиватора организационного поведения» [11]. Развитие студенческого самоуправления как ресурса формирования ценностных механизмов - одно из ключевых условий эффективности управления воспитательной работой в образовательной организации высшего образования.

Главными субъектами студенческого самоуправления являются студенты, личностно-профессиональное становление которых выстраивается как «процесс личностных, субъектных и деятельностных изменений» [3]. Следовательно, студенческое самоуправление должно строиться на основе их субъектной позиции, инициативы, интересов и созидательной активной деятельности, что способствует формированию социального здоровья обучающихся, ключевыми критериями сформированности которого выступают: социальная активность личности; успешная социализация, наличие общественно значимых смыслов и ценностей; социальная ответственность; социальная терпимость; устойчивый социальный иммунитет [9].

М.А. Цветкова отмечает, что студенческое самоуправление формирует и развивает «социально-значимые качества, такие как: ответственность, мобильность, самоорганизованность, решительность, а также готовность к открытому диалогу и взаимодействию» [6].

В.Н. Стегний провел исследование по выявлению позиций студентов относительно студенческого самоуправления и установил, что, по мнению обучающихся, основными направлениями деятельности органов студенческого самоуправления в вузе является: проведение культурно-массовых и спортивных мероприятий, обеспечение студентов информацией по различным вопросам жизнедеятельности вуза и его структурных подразделений; социальная защита и помощь студентам; оказание юридических консультаций; организация научноисследовательской работы со студентами; содействие в решении социально-бытовых вопросов; содействие в трудоустройстве выпускников. Согласно данным, представленным в исследовании, подавляющее большинство студентов (88\%) считают главным направлением работы организацию и проведение культурно-массовых мероприятий. При этом они отмечают, что студенческое самоуправление им необходимо преимущественно для участия в мероприятиях, сплочения студенческого коллектива и получения навыков управленческой деятельности [5].

Таким образом, мы видим, что у обучающихся в процессе активной деятельности в процессе студенческого самоуправления формируются организаторские способности, умение работать в команде как универсальные компетенции, которые могут стать залогом успешной профессиональной деятельности.

Материаль и методы исследования. Исследование было проведено на базе Университета управления«ТИСБИ». Выборку исследования составили 74 студента бакалавриата (1 - 4 курсы) очной формы обучения по направлению подготовки «Менеджмент» в возрасте от 17 до 23 лет.

Цель исследования - выявить субъектную позицию студентов - будущих управленцев о студенческом самоуправлении как условии формирования и развития их личностных и профессиональных качеств.

В рамках исследования мы поставили следующие задачи:

- оценить степень включенности обучающихся в студенческое самоуправление;

- выявить внутреннюю позицию студентов относительно их личностных и профессиональных качеств, формируемых в деятельности студенческого самоуправления;

- выявить наиболее предпочтительные для студентов направленности мероприятий, организуемых студенческим советом; 
- определить пул значимых для студентов предпринимательского вуза личностных и профессиональных качеств, формируемых в процессе студенческого самоуправления и необходимых для их будущей профессиональной деятельности.

Для определения отношения студентов предпринимательского вуза к студенческому самоуправлению мы разработали анкету, включающую вопросы о степени включенности студентов в студенческое самоуправление, направлениях воспитательной работы студенческого самоуправления, личностных и профессиональных качествах, формируемых в процессе участия в студенческом самоуправлении и необходимых для успешной реализации в их дальнейшей профессиональной деятельности.

Для обработки данных, полученных в результате анкетирования, мы использовали контент-анализ и методы математической статистики.

Результаты исследования. В рамках исследования степени включенности студентов в студенческое самоуправление университета/факультета, мы оценивали степень включенности в актив студенческого самоуправления (0-1 баллов), степень включенности в обсуждение вопросов, связанных с жизнью вуза (0-1 баллов), степень участия в мероприятиях, организованных студенческим самоуправлением (0-2 баллов). Ответы респондентов указаны в таблице 1.

Таблица 1

Характеристика ответов респондентов на вопросы, касающиеся степени их включенности в студенческое самоуправление институт/факультета

\begin{tabular}{|c|c|c|c|}
\hline Вопросы & \multicolumn{3}{|c|}{ Ответы } \\
\hline \multirow{2}{*}{$\begin{array}{l}\text { 1. Состоите ли вы в активе студенческого совета } \\
\text { института/факультета и его секторов? }\end{array}$} & \multicolumn{2}{|c|}{ Да } & Нет \\
\hline & \multicolumn{2}{|c|}{$16,22 \%$} & $16,22 \%$ \\
\hline \multirow{2}{*}{$\begin{array}{l}\text { 2. Принимаете ли вы участие в обсуждении вопросов, } \\
\text { связанных с жизнью института/факультета, вносите ли } \\
\text { предложения по улучшению? }\end{array}$} & \multicolumn{2}{|c|}{ Да } & Нет \\
\hline & \multicolumn{2}{|c|}{$19,92 \%$} & $80,08 \%$ \\
\hline \multirow{2}{*}{$\begin{array}{l}\text { 3. Участвуете ли вы в мероприятиях, организованных } \\
\text { студенческим советом института/факультета? }\end{array}$} & Да, часто & Да, редко & Нет \\
\hline & $16,86 \%$ & $43,24 \%$ & $40,89 \%$ \\
\hline
\end{tabular}

Таким образом, в активе студенческого совета факультета состоит 16,22\% студентов; принимает участие в обсуждении вопросов, связанных с жизнью университета/факультета лишь 19,92\% студентов; в мероприятиях, организованных студенческим советом принимает участие более половины опрошенных (60,1\%), но при этом большая часть из них участвует редко $(40,89 \%)$.

Определено мнение студентов о предпочтительных для них направленностях мероприятий, организованных студенческим советом, см. таблицу 2.

Таблица 2

Предпочтительные для студентов направленности мероприятий

\begin{tabular}{|l|l|}
\hline Направленность мероприятия & Доля опрошенных \\
\hline Творческая & $82,04 \%$ \\
\hline Просветительская & $43,26 \%$ \\
\hline Научная & $27,03 \%$ \\
\hline Физкультурно-спортивная & $20,62 \%$ \\
\hline Гражданско-патриотическая & $11,18 \%$ \\
\hline Волонтерская (добровольческая) & $3,7 \%$ \\
\hline
\end{tabular}

На основе выделенных выше критериев и полученных данных мы оценили степень включенности студентов в студенческое самоуправление по 5-ти бальной шкале, где 0 баллов - это низкая степень включенности, 2 балла - средняя степень включенности, 4 балла - высокая степень включенности, см. таблицу 3. 
Таблица 3

Шкала степени включенности студентов в студенческое самоуправление

\begin{tabular}{|c|c|c|c|c|c|}
\hline \multirow{2}{*}{ Степень включенности } & 0 баллов & 1 балл & 2 балла & 3 балла & 4 балла \\
\cline { 2 - 6 } & Низкая & $\begin{array}{c}\text { Ниже } \\
\text { среднего }\end{array}$ & Средняя & $\begin{array}{c}\text { Выше } \\
\text { среднего }\end{array}$ & Высокая \\
\hline Процент студентов & $38,09 \%$ & $37,64 \%$ & $9,16 \%$ & $5,49 \%$ & $9,62 \%$ \\
\hline
\end{tabular}

В рамках решения второй исследовательской задачи студентам было предложено выделить 5 личностных и профессиональных качеств, которые формируются в активной деятельности в контексте студенческого самоуправления (рейтинг ответов представлен в таблице 4).

Таблица 4

Рейтинг личностных качеств, формируемых в системе студенческого самоуправления

\begin{tabular}{|l|l|}
\hline Личностные и профессиональные качества & Доля опрошенных \\
\hline Ответственность & $63,24 \%$ \\
\hline Креативность & $55,00 \%$ \\
\hline Коммуникабельность & $46,35 \%$ \\
\hline Активность & $38,64 \%$ \\
\hline Организованность & $27,54 \%$ \\
\hline Инициативность & $20,47 \%$ \\
\hline Оптимизм & $19,82 \%$ \\
\hline Дружелюбие & $17,32 \%$ \\
\hline Организаторские способности & $16,86 \%$ \\
\hline Целеустремленность & $12,01 \%$ \\
\hline Эмпатия & $10,57 \%$ \\
\hline Заинтересованность & $10,17 \%$ \\
\hline Умение работать в команде & $9,11 \%$ \\
\hline
\end{tabular}

Выявлено, что наиболее предпочтительными направленностями мероприятий, организуемых студенческим советом, является творческая $(82,04 \%)$ и просветительская $(43,26 \%)$ направленность, которые способствуют творческой самореализации обучающихся, удовлетворяют их потребность в получении новых знаний. Установлено, что эмпатию, дружелюбие, коммуникабельность и ответственность студенты считают значимыми для их будущей профессиональной деятельности, а студенческое самоуправление способствует формированию, совершенствованию и развитию данных качеств. Оценена степень включенности обучающихся в студенческое самоуправление: большинство студентов $(75,73 \%)$ показали низкую и ниже среднего степень включенности в студенческое самоуправление. Несмотря на это, большинство опрошенных $(85,14 \%)$ осознают его особую роль различных видов деятельности в системе воспитательной работы вуза для их профессионального становления.

Заключение. Обобщение теоретических установок и диагностических материалов позволило выделить авторскую позицию - активное созидательное участие обучающихся в студенческом самоуправлении способствует формированию, совершенствованию и развитию их личностных и профессиональных качеств обучающихся предпринимательского вуза, а студенческое самоуправление может выступать одним из условий профессионального развития будущих управленцев.

Мы исследовали различные субъектные позиции студентов предпринимательского вуза относительно роли студенческого самоуправления в формировании их личностных и профессиональных качеств и пришли к выводу, что данная форма организации студенческих видов деятельности - одна из важнейших составляющих воспитывающей среды образовательной организации высшего образования, позволяющая развиваться студентам в личностном и профессиональном плане. 
Перспективы дальнейшего исследования мы видим в том, чтобы выявить взаимосвязь между степенью включенности студентов предпринимательского вуза в различные виды деятельности в системе воспитательной работы образовательной организации высшего образования и уровнем профессионального становления обучающихся.

$$
* * *
$$

1. Богданова Р.У. Подготовка студентов-вожатых к созданию воспитывающей среды в образовательных организациях / Р.У. Богданова // Вестник педагогических инноваций. - 2019. - № 1(53). - C. 52-58.

2. Лимонова О.О., Дрожжина Н.Б. Психологические детерминанты профессионально-личностного становления студентов вузов / О.О. Лимонова, Н.Б. Дрожжина // Казанский педагогический журнал. - 2019. - № 2(133). - С. 111-116.

3. Пешкова В.П. Социокультурная среда вуза как фактор личностно-профессионального становления специалиста / В.П. Пешкова // Казанский педагогический журнал. - 2018. - № 1(126). - С. 72-77.

4. Самородова В.В. Студенческое самоуправление как фактор формирования социально безопасной среды вуза / В.В. Самородова // Казанский педагогический журнал. - 2019. - № 6(137). - С. 43-48.

5. Стегний В.Н. Студенческое самоуправление глазами студентов / В.Н. Стегний // Власть. - 2016. № 4. - С. 169-175.

6. Цветкова М.А. Студенческое самоуправление: функции и механизмы реализации в современных условиях (на примере координационного совета института педагогики и психологии костромского государственного университета) / М.А. Цветкова // Казанский педагогический журнал. - 2016. - № 6(119). - C. 93-96.

7. Цибульникова В.Е. Здоровьеформирующая и здоровьесберегающая среда как компонент образовательной среды школы / В.Е. Цибульникова // Наука и школа. - 2018. - № 1. - С. 156-165.

8. Цибульникова В.Е. Общие основы менеджмента в образовании: учебное пособие для студентов педагогических вузов / В.Е. Цибульникова. - Москва. - 2016. - 231 с.

9. Цибульникова В.Е. Социальное здоровье участников образовательного процесса школы и его критерии / В.Е. Цибульникова // Школа будущего. - 2015. - № 4. - С. 134-145.

10. Цибульникова В.Е. Ценностно-ориентированное управление педагогическим коллективом общеобразовательной организации / В.Е. Цибульникова // Бизнес. Образование. Право. - 2019. - № 2(47). - С. 429-434.

11. Ясвин В.А., Рыбинская С.Н. Вестник Московского городского педагогического университета. Серия: Педагогика и психология / В.А. Ясвин, С.Н. Рыбинская. - 2015. - № 4(34). - С. 8-26.

Болотников А.А, Гимадеев Р.Н.

Влияние физической культуры и спорта на социализацию студентов

Университет управления «ТИСБИ» (Россия, Казань)

doi: $10.18411 / l j-02-2021-122$

idsp: ljournal-02-2021-122

\section{Аннотация}

Социализация представляет собой процесс социального становления человека, формирования его социального статуса.Растёт интерес государственной образовательной политики к возможностям физической культуры и спорта при реализации задач подготовки будущих специалистов. Физическая культура и спорт с помощью своих специфических средств реально положительно влияют на процесс социализации личности студентов. В процессе и в результате занятий физической культурой или спортом происходит гармоничное сочетание физического и духовного, идейного и трудового, нравственного и эстети-ческого воспитания, что влияет на повышениеуровня социальной зрелость занимающихся.

Ключевые слова:социализация, студенчество, физическая культура, спорт. 